\title{
Preparation of Calebin-A Liposomes and its The Thousand-Year-Old Shamanistic Tradition of Healing Touch in the Northeast Australian Rain Forrest
}

\begin{abstract}
We have interviewed a shaman, Harold "Mooks" Tayley, who claims to be a shaman in the original traditional line of the rain forest shamans, and we have observed the healing ritual. The traditional shamans of the North East Australian rain forest where aboriginals have been living for thousands of years are using touch and talk for healing. They enter a state of trance that allows them to see the blocked and disturbed body-energy (information) and they are able to manipulate the blockages and free the body and mind from the energetic causes of diseases.

The existence of remaining healer-shaman in the ancient line of the rainforest aboriginal medicine men calls for thorough scientific exploration and documentation of the way different people and diseases are treated, and for documenting of the affectivity of the shamanistic treatment. We encourage the Australian authorities to fund research in aboriginal shamanistic healing, as this might be a way to support the Australian indigenous cultures, and preserve inherited tradition and wisdom of the tribes which are very close to getting lost forever.

The acknowledgment of a living, healing tradition might also help improving the respect and understanding for the ingenious people, who lack written traditions. A deep, scientific analysis of their healing art might also help understanding the spiritual dimensions of ancient and new aboriginal art, much of which is about spiritual growth and healing.
\end{abstract}

Review Article

Volume 8 Issue 3 - 2017

Søren Ventegodt* and Pavlina Kordova

Nordic School of Holistic Medicine, Denmark

*Corresponding author: Søren Ventegodt, Quality of Life Research Center, Research Clinic for Holistic Medicine, Nordic School of Holistic Medicine, Denmark, Email: ventegodt@livskvalitet.org

Received: November 19, 2016 | Published: August 03, 2017

\section{Introduction}

A significant body of research on aboriginal healing exist [1-39] but very little has been written on the healer-shamans of the North East Australian rain forest. The ingenious people of Australia, the aboriginals, have an ancient tradition of healing using only talk and touch as the active principles. While the shamans and healers of many other pre-modern cultures use psychedelic drugs for healing and self-exploration, i.e. the shamans of the amazon jungle (DMT in Ayahuasca [40]), the North American natives (Mescaline in San Pedro and Peyote, psilocybin in magic mushrooms [41]), and the African Sangomas (Ibogain in Iboga [42]), the shamans of the Australian rain forest do not use any drugs or medicine plants for their sacred, healing rituals (called "Molgulbanga") but only touch and talk. While they know that several jungle plants can be used as pain killers and antiseptics, they believe that these plants only remove the patient's symptoms, they do not heal the patient. For healing, touch and talk are necessary. The aboriginals do not have a written language, so the tradition of healing is oral, one shaman passing the tradition on by giving an initiation into the art of healing to his apprentice. The young followers must be recognized as "a person having the gift of magical power of healing" before he is taken as a student; the talent of healing are seen as an inborn quality, and this quality is always noticed in the coming shaman already as a young child.
In October 2016 we travelled though the northern Australian rainforest from Cairns to Cock Town from tribe to tribe to find healers working in an unbroken tradition of aboriginal healers. After weeks of search we managed to find one such shaman, Harold Tayley (with the native/spiritual name "Mooks"), who claimed to be the last existing original shaman healer in the rainforest of Northern Queensland, which 150 years ago had about 10 tribes with at least as many shamans.

The sad history of the North Australian aboriginals has been documented in a rapport on the matter from 1864 by James Morrill [43], who worked as a mediator in the bloody conflict between the British settlers at that time and the ten original aboriginal tribes of the rain forest. Originally a few thousand aboriginals lived in these tribes but the aboriginals were soon decimated in the sanguine conflict with the white settlers. We find it therefore likely to be true that Harold Tayley is the last aboriginal medicine man in the unbroken line of the North East Australian rain forest shamans.

\section{Meeting our Shaman}

We finally met Harold Tayler, a 45-year-old shaman claiming to have 31 years of healing practice, at the Mossman Gorge Centre the 12th of October 2016, after trying for several days to get in contact with him, which was very difficult as the tribe protected 
him and refused to give us his contact information, and forbid us to go near to his house; we were not even allowed to enter the village where he lived in the rain forest.

But suddenly a young woman came to us, and said that we could meet Harold the next morning 8am at the center. It was our feeling that we had been observed and tested; only if we respected not to go there could we have the meeting and we did. And we did that wisely, in spite of the obvious frustration of having travelled $20.000 \mathrm{~km}$ from Denmark, only to be stopped a few kilometers from the location of the only living shaman. We were very happy for the development of the situation, finally being able to meet the shaman for an interview.

Harold received us very kindly; he looked sad in his eyes, and gave a feel of being infinitely wounded; he also started our meeting by telling us about the inhumane massacres on his people, the rain forest aboriginals, carried out repeatedly by the white man, as they annexed more and more of their land, until all fertile land usable for good hunting was gone and changed into the white people's sugar cane plantations.

Harold speaks several languages: several native languages and also a good English. He works today both as healer, healing about 3 patients a week, and as rain forest guide for turists, the latter giving him a fair income.

He tells us that he early in his life was chosen as medicine man. He was raised by his uncle, a shaman carrying the English name George Mosgrave and also by his grandfather, a shaman with the English name Harry Sikes. These people were the last shamans of the Kuku Nungl tribe. (Harold does not know how "Nungl" is spelled, as there is no written language of the Kuku Nungl tribe, so "Nungl" is the phonetic spelling.)

"You gonna be helping many people", said his uncle always to him as a child, and he had no problem believing that. He was the only child 8 years old when he was chosen to be the next shaman in the line, and he also started to practice healing already as a child He remembers healing as an 8-year old boy, but he was 14 (maybe 16 , he is not clear about his age) when he finally was initiated as shaman. Harold tells us about his successes of healing and there are many, but none of them, it seems, has been documented scientifically, as it is often the case with native healers.

One story is about a 6-year old girl with a brain tumor, which he healed many years ago, and the girl became well and lives this day. Another is about a 33-year old man who due to a cerebral bleeding lost his ability to talk and suffered from numerous fits; today he talks and the fits has disappeared.

Both physical and mental disorders are cured by the shaman, and also problems in behavior, social intercourse and intimate relationships are subject to healing. "Anything can be healed", says Harold, "but it sometimes takes more than one healing session, often two or three, and it is very important that the patient is involved the healing, working on caring for himself, giving selfcare in the form of daily healing touch and massage with oil preferably Emu-oil", says Harold. The time healing takes is related to the time the sickness has been developing.

\section{The Shamanistic Healing Trance}

The key to shamanistic healing is the trance, explains Harold. To be trained as a healer-shaman, the child learns to chant, and as the art of chanting develops, consciousness gets more silent and deeper, and one day the child or young man are able to enter the state of trance (also called "meditation") and this ability signifies that he is ready for the initiation as shaman. The initiation is a long series of rituals, where dancing, smoking, chanting, and meditating all prepares the new shaman for his art of healing guided by energetic seeing.

In the state of trance, the shaman can see the energy of the body and mind, and also the problems causing the disease on the energetic level. Harold tells us that his grandfather used a piece of rag or old cloth to cower the body of his patient, where after he looked through the cloth, energetically, for the problem, and in this trance-seeing he got a clear picture of the patient's state, including a complete knowledge of the past of the person and his disease. The shamanistic trance is described as omniscient, similar to the descriptions we find of the shamanistic consciousness from the other continents. Harold uses a handkerchief for this purpose.

As soon as the medicine man is in trance he can not only see and understand the problems on an energetic level, he can also manipulate the energies. Using his intention, he removes the blocked and dark energies, by sucking them up in his own body, and thereafter sending them out into the universe where they came from. To avoid being disturbed by the bad energies, shamans of Kuku Nungl line use sweat to protect themselves, Harold explains. The sweat is taken from the arm pits during the procedure of healing.

Another important ingredient of the healing ritual is water. Cold water is used to remove bad energies, and warm water is an important part of the self-treatment practice for the patient to continue on his own.

Harold explains that there originally also were female healers in his tradition, and these were trained by the female medicine woman. The principles of healing were the same, but the methods were a bit different. Today the female line has been broken and lost. If Harold himself dies now the male line will also be lost; so Harold is looking for children with the power to heal, which he can train to be shamans, and he has now found a few children with the gift, so there is hope that the line will continue.

We talk about the principal causes of disease and Harold explains that the aboriginal healer acknowledges different levels of causes, physical causes like bad food, snakes, or poisonous plants, and mental and spiritual causes like spiritual problems and negative mental and spiritual energies the person have picked up through his life's events or have in his blood by heritage.

\section{The Significance of Nature}

Healing rituals are done at the most beautiful places in the rain forest, often a place where a river has been formed into a deep water whole by the streaming water in the rainy season, a place where clear, blue water full of fish and other life forms reflect the 
colors of the flowers, trees, birds and other life of the rain forest.

The aboriginals have a stunning sense of beauty, and the places they select for ritual purposes are according to the aboriginal's power places, places where it is easy to connect to nature, or more precisely to the spirit of nature, or to the "spirit" for short.

For some reason the white man has had big difficulties understanding the aboriginal's relation to nature; having lost closeness with nature himself it has been almost impossible to understand the way the aboriginal people live connected to nature, and as one with the greater wholeness and the universe at large.

To live in accordance with the spirit creates health, to live in conflict with the spirit creates disease. This is the core of the aboriginal belief when it comes to the causes of disease. It is close to the understanding of modern researchers like Aaron Antonovsky (the concept of "salutogenesis") [44,45] and Mihaly Chiksentmihaly (the concept of "flow") [46].

\section{A Healing Session}

To make a direct observation of how Harold works I (SV) ask Harold to heal my hand, which has been swollen and painful after an attack of Herpes Zoster 6 month ago, as the only symptom remaining. Harold accepts to do the healing.

We meet in a sacred place in the jungle, a place obviously meant for healing and sacred rituals. There is an alter with different minerals and fruits used for dies, spears and shields used by the Kuku Nungl tribe traditionally, and a bucket of water, taken from the river that flows next to the sacred place. There are benches placed around an open space in the jungle, with space for about 50 people.

Harold enters his state of trance immediately, and then he first uses his handkerchief and looks true it. "I see too much fluid in the tissue, he said, it looks like inflammation, and you have had it for some time, like a year", he says. His diagnosis is fast, precise and correct. He then starts massaging the place and anatomical structures in my hand, where I have a problem, again with total precision. It will take some time to heal, he said, massage it every day with Emu-oil, and get back in contact with me after some time.

His touch where very pleasant, very intimate, very good, loving and kind. Being trained as a massage therapist and bodyworker myself, I had no problem recognizing a skillful peer in action. The healing is soon over; it took all in all 10 minutes. Harold is not charging me for the session, in spite of me offering to pay him.

"I am also teaching on the parking lot of Thala Beach Lodge in Port Douglas every Monday night from 6. PM", he says smilingly. So obviously his healing work is not limited by the demand of a wonderful jungle location like the one we were in, a parking place works also. After the healing the hand got slowly better, as predicted by Harold Tayley.

\section{Analysis}

Our findings interviewing shaman Harold Tayley is in line with earlier findings and descriptions of the healing work of Australian aboriginals [1-39]. It is interesting to compare it also to Marlo Morgan's famous (fictive) description of healing in her book "Mutant Message Down Under" focusing on the Aboriginals of the central dessert of Australia. According to Marlo these people also uses touch for healing, in a state of consciousness that gives them admission to secret information about the body structure, which they in a state of trance can access, change and manipulate to heal the patient. This is a fairly good descriptions of the healing work of Harold Tayley.

Interestingly enough Marlo's book what brutally criticized in Australia, where media called it "Marlo's Mutant Fantasy" and the like, and many people found the omniscient state of the healershaman highly unlikely.

We also notice that a deep and ego-free state of consciousness similar to the state described by our shaman Harold Tayley is found in the shamanistic traditions from all continents.

It is also interesting that the Australian aboriginals coming from very different areas of the vast Australian continent seems to use basically the same philosophical concepts and practical methods of healing.

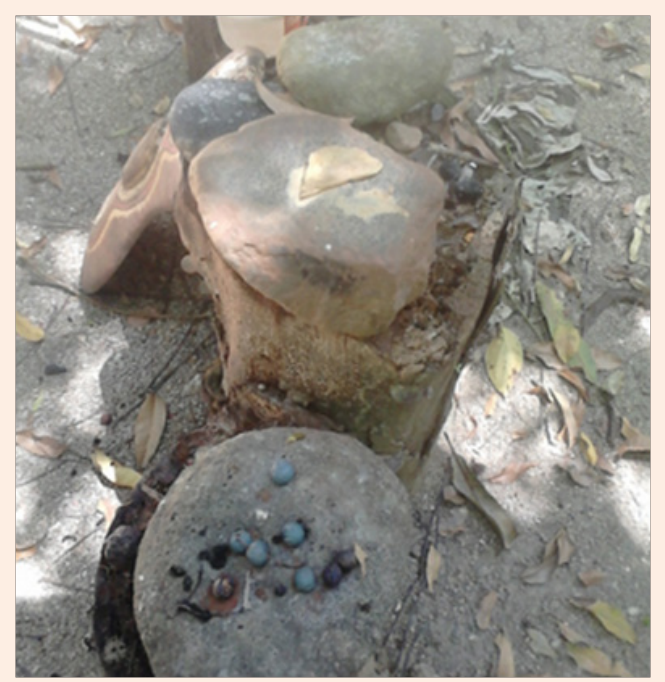

Figure 1: An important part of a healing ritual is body painting. Paint is produced from minerals and berries. In the original ritual the patient, the shaman and the participants in the ritual are all naked, only waring body paint.

It is remarkable that healing touch is used by the Australian aboriginals without the use of any hallucinogenic substances, because this is rare in the shamanistic world. This makes the healing system of the Australian aboriginals closer to the old European system of mind-body medicine known from Hippocrates, than to the other shamanistic healing systems.

Harold appears to be a skillful bodyworker, and his diagnosis is totally compatible with modern medical diagnostics in spite of 
him having no training in western medicine. His energetic seeing call it intuition if you like, gives him precise information about the problem and empowers him to act directly and effectively, leaving us without doubt in his healing capabilities as a shaman.
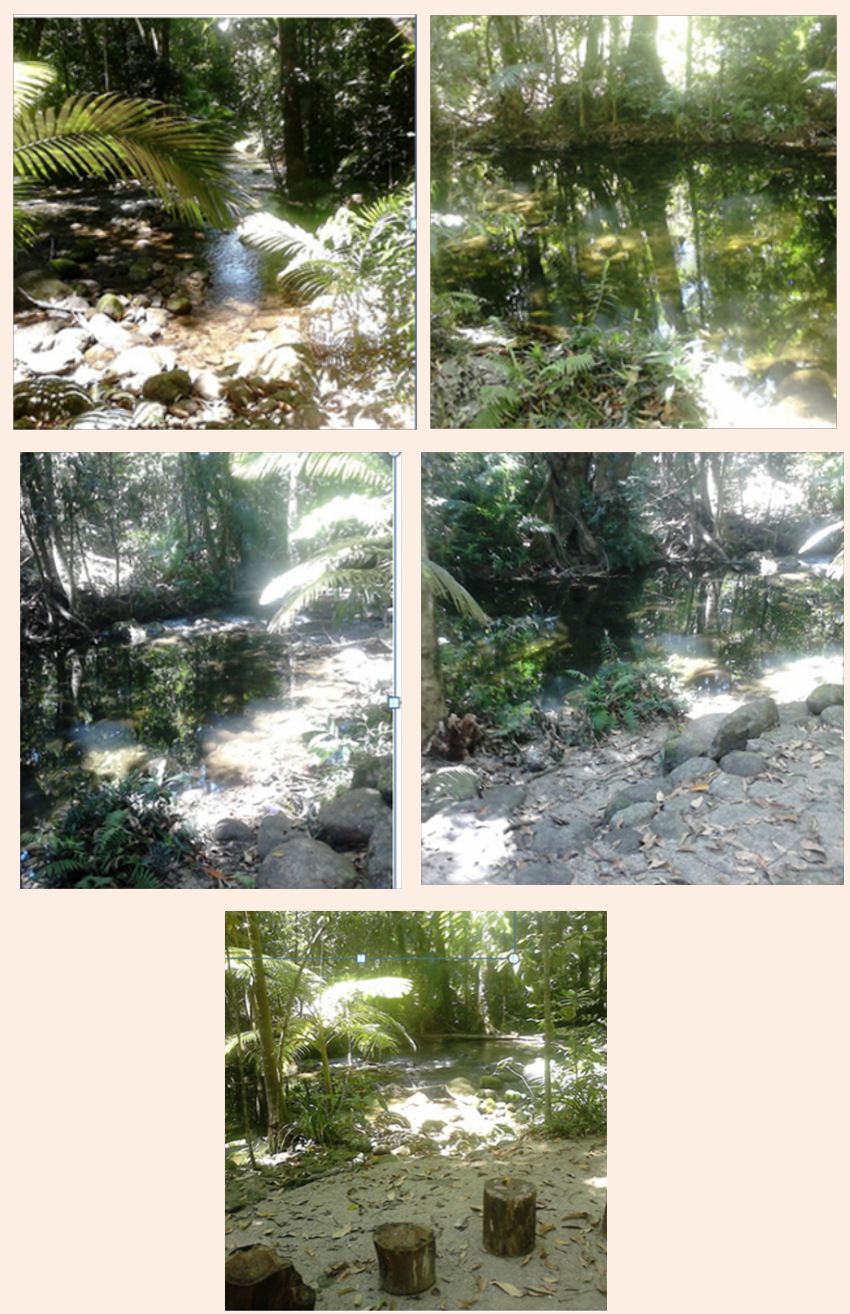

Figure 2: These pictures are all taken from the healing cirkle in the jungle used for healing by the shaman. One is hit by the astonnishing beuaty of the rainforrest; the water is clear and fresh drnking water, and the river is also used for swimming and bathing.

The Australian rain forrest is suprisingly frindly; very few insects bite you, snakes avoid people, and spiders live high in the trees. The aboriginals have no reason to wear cloth, and they did not know of hiding their body, until the white man arrived only hundred years ago. Being one with nature is seen as the natural and healthy state.

Compared to the Hippocratic healing tradition of mind-body medicine [47] the Aboriginal healing seems to be competent and adequate; most of the essential elements for healing found in the ancient Hippocratic healing system, like confrontation of the problem on an emotional/energetic level, understanding the body as energy and information, and handling the patient's consciousness [48-54], seems to be found also in the Australian aboriginal shamanistic healing system.

\section{Conclusion}

The existence of one remaining healer-shaman in the ancient line of the rainforest aboriginal medicine men calls for thorough scientific exploration and documentation of the way different people and diseases are treated, and for documenting of the affectivity of the shamanistic treatment.

We have no reason to doubt the many successful stories of Harold's healings, but have chosen only to tell about a few of them, as this is better dealt with in a news paper, which should be based on detailed clinical research including the case records and documented diagnoses from a modern medical clinic or hospital.

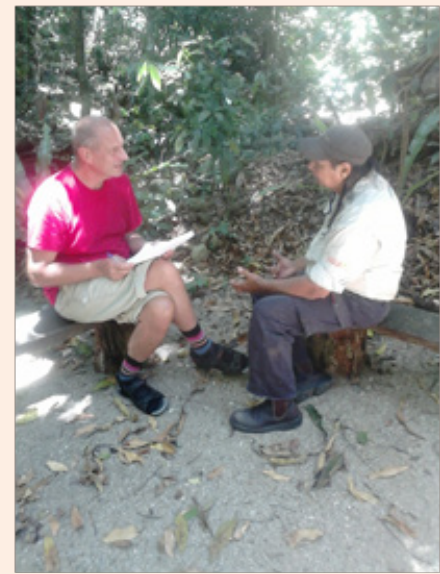

Figure 3: Søren Ventegodt interviews shaman $\mathrm{NN}$ before he demonstrates a healing session.
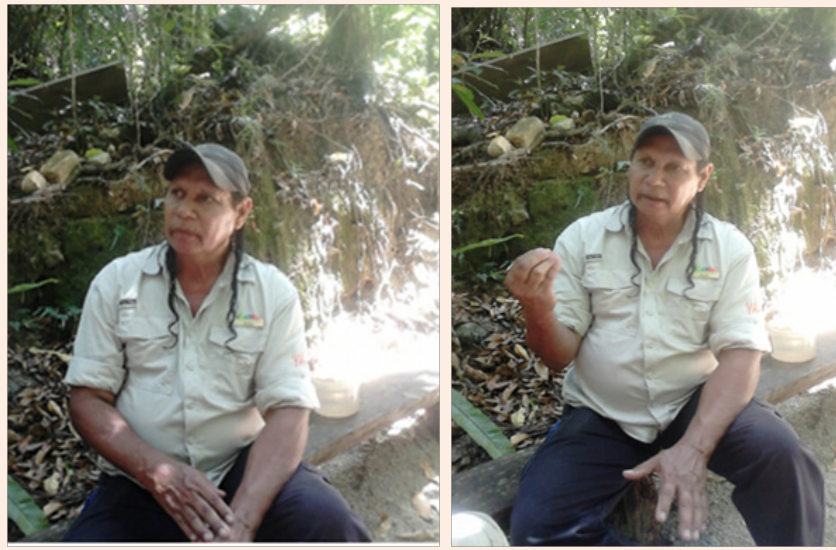

Figure 4: An important part of the treatment is that the shaman explains the spiritual courss of the disease fo rthe patienet. The reason for you being isck is that yuou have lost yoyr connection to reality nature around you, and the world as it is. 
We encourage the Australian authorities to fund research in aboriginal shamanistic healing, as this might be a way to support the Australian indigenous cultures, and preserve inherited tradition and wisdom of the tribes which are very close to getting lost forever.
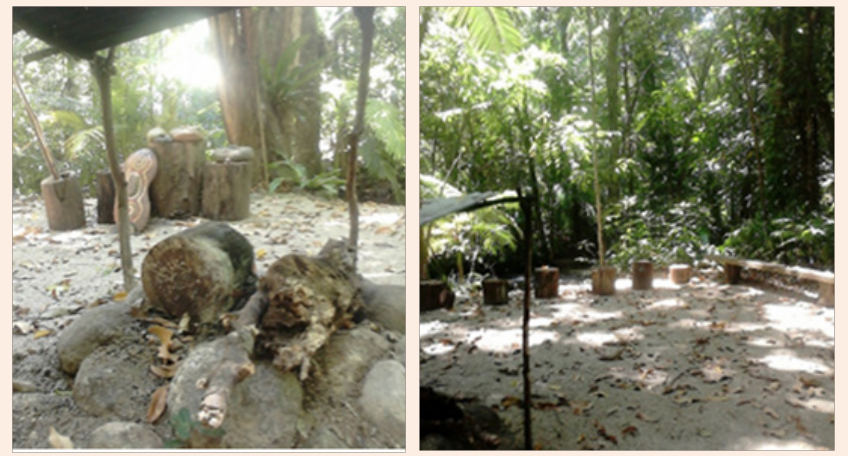

Figure 5: The location for the place for healing rituals are chosen as the most beutyful spots in the jungle, always close to a river, as water is an important part of the ritual.

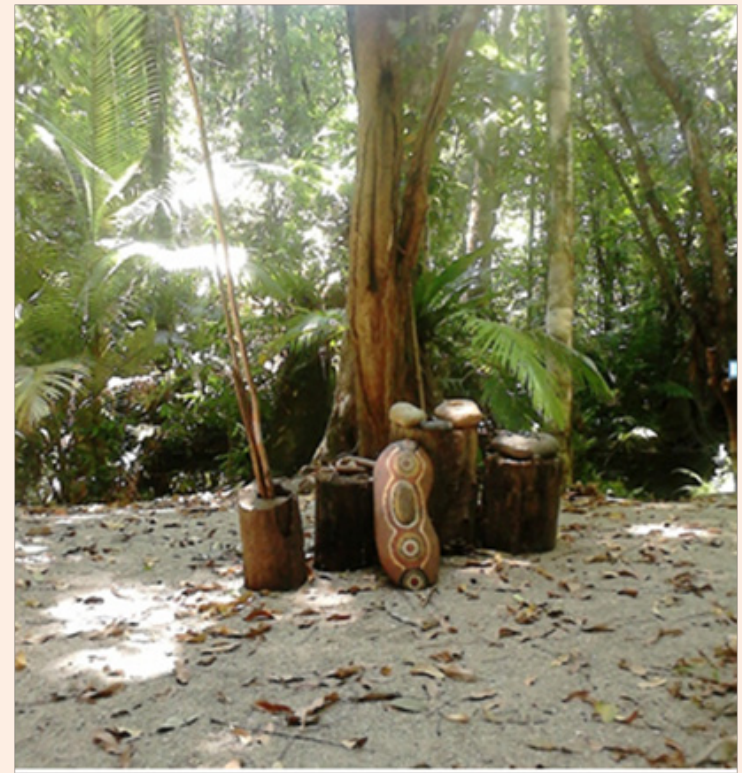

Figure 6: A small altar contains the traditional object of the aboriginals, the spear and sheald, the body paint, the sacred healing water from the river in a bucket, and very little more.

The acknowledgment of a living, healing tradition might also help improving the respect and understanding for the ingenious people, who lack written traditions. A deep, scientific analysis of their healing art might also help understanding the spiritual dimensions of ancient and new aboriginal art, much of which is about spiritual growth and healing.
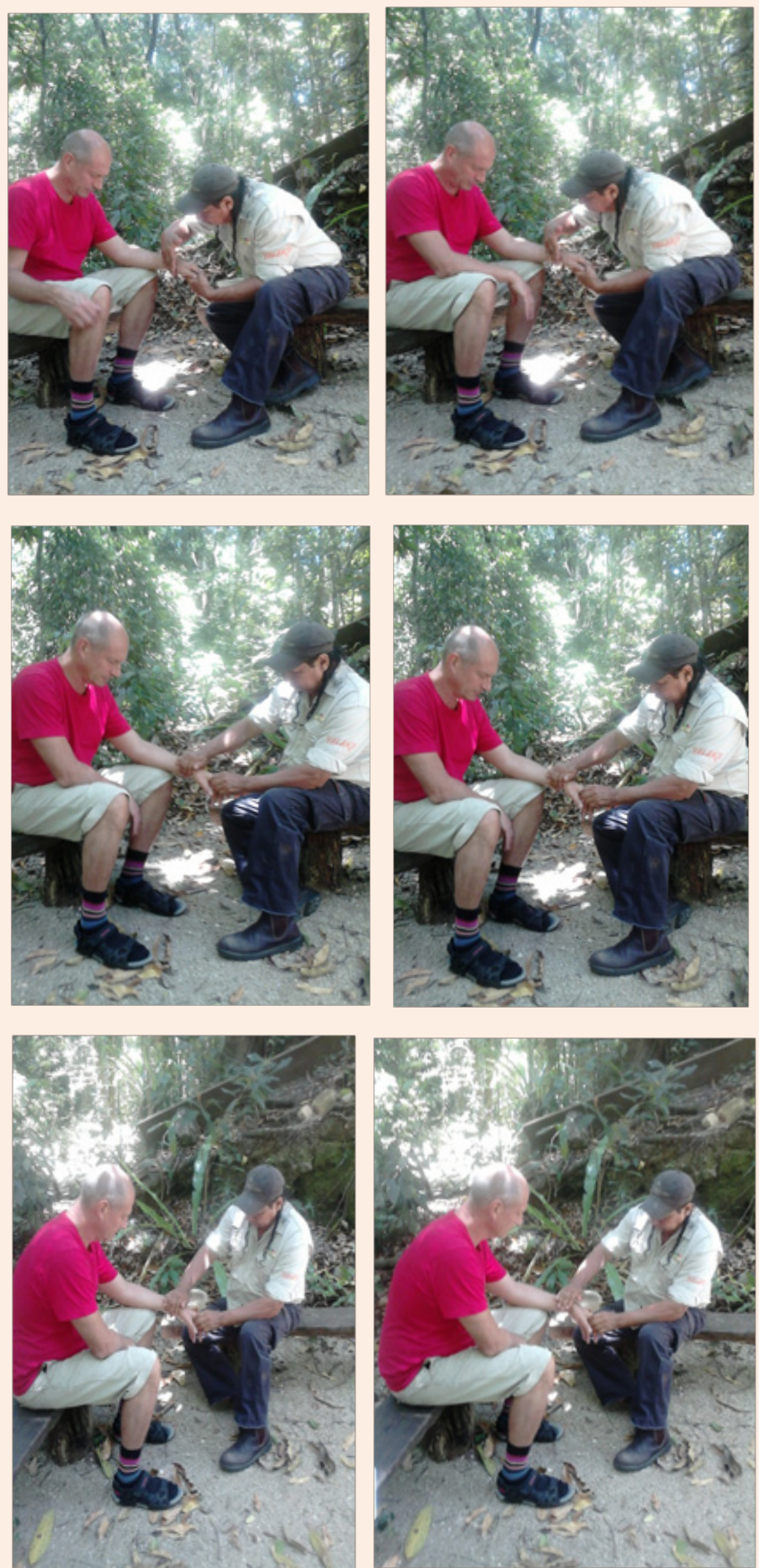

Figure 7: Touch is the key to healing in the aboriginal culture, and according to shaman NN, the last exising shaman in the unbrokan line of rainforrest shamans, this is how is has been for thousand of years in the North Australian Rainforrest. The grib is firm and precise, and the result is a clear contact is with the deep body tissues which are troubled by disease. The shaman got his information about the disease from "energetic seeing" which happens in a state of trance. 


\section{Acknowledgments}

We thank shaman Harold "Mooks" Tayley, Mossman Gorge Village (e-mail to Mossman Gorge Center: rose.torcasio@ mossmangorge.com.au or tim.ellis@mossmangorge.com.au, Phone: Australia (04) 31175582) for his kind assistance and willingness to give an interview and healing session which is the basis of this article.

The research was carried out in accordance with the Open Source protocol for Clinical Holistic Medicine and it followed the ethical standards of International Society for Holistic Health. The Danish Quality of Life Survey, Quality of Life Research Center and the Research Clinic for Holistic Medicine, Copenhagen, was from 1987 till today supported by grants from the 1991 Pharmacy Foundation, the Goodwill-fonden, the JL-Foundation, E Danielsen and Wife's Foundation, Emmerick Meyer's Trust, the FrimodtHeineken Foundation, the Hede Nielsen Family Foundation, Petrus Andersens Fond, Wholesaler CP Frederiksens Study Trust, Else and Mogens Wedell-Wedellsborg's Foundation and IMK Almene Fond. The research in quality of life and scientific complementary and holistic medicine was approved by the Copenhagen Scientific Ethical Committee under the numbers (KF)V. 100.1762-90, (KF) V. 100.2123/91, (KF)V. 01-502/93, (KF)V. 01-026/97, (KF)V. 01162/97, (KF)V. 01-198/97, and further correspondence.

Conflicts Of Interest: Authors declare no conflicts of interest.

\section{References}

1. Aboriginal Resource and Development Services (1993) 'Galka Djama' (Sorcery) and Its Increasing Use. Information Paper Number 4. Aboriginal Resource and Development Services, Darwin, Australia.

2. Armstrong MJ, Fitzgerald MH (1996) Culture and disability studies: an anthropological perspective. Rehabilitation Education, 10: 247304.

3. Arthur JM (1996) Aboriginal English. Oxford University Press, Melbourne, Australia.

4. Berndt $\mathrm{CH}$ (1964) The role of the native doctor in Aboriginal Australia. In: Kiev A (Ed.), Magic, Faith and Healing: Studies in Primitive Psychiatry Today. The Free Press, New York, USA, pp. 264282.

5. Biernoff D (1982) Psychiatric and anthropological interpretations of 'aberrant' behaviour in an Aboriginal community. In: Reid J (Ed.), Body Land and Spirit: Health and Healing in Aboriginal Society. St Lucia, Qld: University of Queensland Press, pp.139-153.

6. Brady M (1995) Culture in treatment, culture as treatment. A critical appraisal of developments in addictions programs for Indigenous Northern Americans and Australians. Soc Sci Med 41(11): 14871498.

7. Cawte J (1996) Healers of Arnhem Land. University of New South Wales Press, Sydney, Australia.

8. Cawte J (1996) Medicine Is the Law: Studies in Psychiatric Anthropology of Australian Tribal Societies. University Press of Hawaii, Honolulu, USA.
9. Devanesen D (1985) Traditional Aboriginal medicine and the bicultural approach to health care in Australia's Northern Territory. In: Larkins KPMcDonald D \& Watson C (Eds.), Alcohol and Drug Use in a Changing Society. Alcohol and Drug Foundation, Australia, p. 3341.

10. Eastwell H (1973) The traditional healer in modern Arnhem Land. Medical Journal of Australia 2: 1011-1017.

11. Elkin AP (1994 Aboriginal Men of High Degree: Initiation and Sorcery in the World's Oldest Tradition. St Lucia, Qld: University of Queensland Press, Australia.

12. Glynn R (1993) Some perspectives on cross-cultural rehabilitation with remote area Aboriginal people. Australian Occupational Therapy Journal 40: 159-162.

13. Gray D (1979) Traditional medicine on the Carnarvon Aboriginal Reserve. In: Berndt RM, Berndt CH (eds). Aborigines of the West: Their Past and Their Present. University of Western Australia Press, Perth , Australia , pp. 169-182.

14. Harris S (1988) 'Coming up level' without 'losing themselves': The dilemma of formal tertiary training for Aborigines. In: Harvey B \& McGinty S (Eds.), Learning My Way: Papers from the National Conference on Adult Aboriginal Learning. Institute of Applied Aboriginal Studies, Perth, Australia, pp. 169-187.

15. Honeyman PT, Jacobs EA (1996) Effects of culture on back pain in Australian Aboriginals. Spine 21: 841-843.

16. Hunter E (1993) Aboriginal Health and History: Power and Prejudice in Remote Australia. Cambridge University Press, Cambridge, UK.

17. Johnson S (1978) Some Aspects of the Tiwi Concept of Health. Tiwi Press, Ngiui, Australia.

18. Kleinman R, Eisenberg L, Good B (1978) Culture, illness and care: clinical lessons from anthropologic and cross cultural research. Ann Intern Med 88(2): 251-258

19. McLennan W (1997) 1994 National Aboriginal and Torres Strait Islander Survey: Social Atlas. Australian Bureau of Statistics, Canberra, Australia.

20. Memmott P (1997) Improving Aboriginal People's Access to Alice Springs Hospital Services. Alice Springs: Territory Health Services, 1997.Territory Health Services. Annual Report 1996/97. Darwin: Territory Health Services, Northern Territory Government, Australia.

21. Mobbs R (1991) In sickness and health: the sociocultural context of Aboriginal well-being, illness and healing. In: Reid J \& Trompf P (Eds.), The Health of Aboriginal Australia. Harcourt Brace Jovanovich Publishers 292-325.

22. Morgan DL, Slade MD, Morgan CMA (1997) Aboriginal philosophy and its impact on health care outcomes. Aust N Z J Public Health 21(6): 597-601.

23. O'Connor MC (1993) 'Women's business': An introduction to the cultural aspects of Aboriginal obstetric and gynaecological care. Perinatal Newsletter 21: 3-6.

24. Peile AR (1997) Body and Soul. An Aboriginal View. Hesperian Press, Carlisle, WA, Australia.

25. Reid J \& Mununggurr D (1977) We are losing our brothers: sorcery and alcohol in an Aboriginal community. Med J Aust 2(4Suppl): 1-5. 
26. Reid J, Williams N (1984) 'Voodoo death' in Arnhem Land. Whose reality? American Anthropologist 86: 121-133.

27. Reid J. Medicine and health: the traditional systems. In: Reid J (ed.). Body Land and Spirit: Health and Healing in Aboriginal Society. St Lucia, Qld: University of Queensland Press, 1982; 91-95.

28. Reid J. Sorcerers and Healing Spirits. Canberra: Australian National University Press, 1983.

29. Saggers S \& Gray D. Aboriginal Health and Society: The Traditiona and Contemporary Aboriginal Struggle for Better Health. Sydney: Allen and Unwin, 1991.

30. Scarlett N, White N, Reid J. 'Bush medicines': The pharmacopoeia of the Yolngu of Arnhem Land. In: Reid J (ed.). Body Land and Spirit: Health and Healing in Aboriginal Society. St Lucia, Qld: University of Queensland Press, 1982; 154-191.

31. Soong FS. Role of the margidjbu (traditional healer) in western Arnhem Land. Medical Journal of Australia 1983; 1: 474-477.

32. Taylor JC. A pre-contact Aboriginal medical system on Cape York Peninsula. Journal of Human Evolution 1977; 6: 419-432.

33. Taylor JC. Murri doctor or nursing sister? Aboriginal and Islander Health Worker Journal 1977; 1: 27-39.

34. Tidemann SC, Bohme J, Burnett R et al. Aboriginal Patient Survey Tools and Processes: Survey of Aboriginal People's Stay in Hospital. Batchelor, NT: Batchelor College, 1996.

35. Tonkinson M. The mabarn and the hospital: The selection of treatment in a remote Aboriginal community. In: Reid J (ed.). Body Land and Spirit: Health and Healing in Aboriginal Society. St Lucia, Qld: University of Queensland Press, 1982; 225-241.

36. Toussaint S. Aboriginal and non Aboriginal healing, health and knowledge: Sociocultural and environmental issues in the West Kimberley. Aboriginal Health Information Bulletin 1989; 12: 30-35.

37. Tynan BJ. Medical systems in conflict: a study of power. Diploma of Anthropology thesis. Sydney: University of Sydney, 1979.

38. Waldock DJ. A review of Aboriginal health beliefs and their incorporation into modern Aboriginal health delivery systems. Australian Health Surveyor 1984; 16: 3-13.

39. Weeramanthri T. 'Painting a Leonardo with finger paint': Medica practitioners communicating about death with Aboriginal people. Social Science Medicine 1997; 45: 1005-1015.
40. Luna E, White, S. Ayahuasca reader. Santa Fe, NM: Synergetic Press, 2000

41. Anderson EF. Peyote. The divine cactus. Tucson, AZ: Univ Arizona Press, 1996

42. Grof S. The great awakening: Psychology, philosophy, and spirituality in LSD psychotherapy. Albany, NY: State University of New York Press, 2003.

43. Morril J. 17 years wandering among the Aboriginals / James Morril : with photographs published by Eric Mjoberg, 1918. Virginia, N.T. : D. Welch, 2006.

44. Antonovsky A. Health, stress and coping. London: Jossey-Bass, 1985

45. Antonovsky A. Unravelling the mystery of health. How people manage stress and stay well. San Francisco: Jossey-Bass, 1987.

46. Csikszentmihalyi, M. Flow. Optimaloplevelsens psykologi. Munksgaard, 1991.

47. Jones WHS. Hippocrates. Vol. I-IV. London: William Heinemann, 1923-1931.

48. Ventegodt S, Merrick J. Principles of holistic psychiatry. A textbook on evidence-based holistic medicine for mental disorders. New York: Nova Sci, 2010

49. Ventegodt S, Merrick J. Sexology from a holistic point of view. A textbook of classic and modern sexology. New York: Nova Sci, 2011.

50. Ventegodt S, Merrick J. Textbook on Evidence-Based Holistic Mind-Body Medicine: Basic Philosophy and Ethics of Traditional Hippocratic Medicine. New York: Nova Science, 2012.

51. Ventegodt S, Merrick J. Textbook on Evidence-Based Holistic MindBody Medicine: Basic Principles of Healing in Traditional Hippocratic Medicine. New York: Nova Science, 2012.

52. Ventegodt S, Merrick J. Textbook on Evidence-Based Holistic MindBody Medicine: Holistic Practice of Traditional Hippocratic Medicine. New York: Nova Science, 2013.

53. Ventegodt S, Merrick J. Textbook on Evidence-Based Holistic MindBody Medicine: Research, Philosophy, Economy and Politics of Traditional Hippocratic Medicine. New York: Nova Science, 2013.

54. Ventegodt S, Merrick J. Textbook on Evidence-Based Holistic MindBody Medicine: Sexology and Traditional Hippocratic Medicine. New York: Nova Science, 2013. 